\title{
The Status of Professional Vocabulary in the Language System
}

\author{
Vinogradov Daniil Vadimovich ${ }^{1}$ \\ Professor of the University of Foreign Studies Hanguk, \\ Seoul, Korea. \\ (date of receiving: January, 2020; date of acceptance: May, 2020)
}

\begin{abstract}
Although in various classifications of social dialects the professional language (professional lexical system) is singled out sufficiently clearly, but its internal heterogeneity and terminological identification have long been the most complex theoretical problems. The professional vocabulary has received in the Russian linguistic tradition a lot of different names: argot professional vocabulary, professional argo, professional argotisms (B.A.Larin, D.S.Likhachov), professional jargons, professional jargon words (V.M.Zhirmunsky, L.P.Krysin), professional terms, professional terminology (B.L.Bogorodsky, O.N.Trubachev), not standard professional vocabulary, industry jargon words (M.A.Grachev), etc. In order to eliminate terminological inaccuracy and reveal the basic properties of the professional vocabulary is classified in the article according to the following criteria: nomination methods, normative, functional-style characteristics, emotional-expressive characteristics, dictionary fixation. The proposed classification allows us to identify three groups of vocabulary terminology, professional vocabulary and professional jargon - each of which has its own characteristics. It seems that the identified criteria and characteristics of a professional language can be considered as basic.
\end{abstract}

Keywords: Russian Language, Professional Vocabulary, Sociolect (Social Dialect), Terminology, Jargon.

1. E-mail: daniil_vinogradov@icloud.com 


\title{
Статус профессиональной лексики в системе языка
}

\author{
Виноградов Даниил Вадимович ${ }^{1}$ \\ Профессор, Университет иностранных языков Хангук, \\ Сеул, Корея. \\ (дата получения: январь 2020 г.; дата принятия: май 2020 г.)
}

\begin{abstract}
Аннотация
Если в различных классификациях социальных диалектов профессиональный язык (профессиональная лексическая система) вычленяется достаточно четко, то его внутренняя неоднородность и терминологическая идентификация давно являются сложнейшими теоретическими проблемами. Лексика профессиональной речи получила в отечественной традиции множество различных наименований: арготическая профессиональная лексика, профессиональное арго, профессиональные арготизмы (Б.А. Ларин, Д.С. Лихачев), профессиональные жаргоны, профессиональные жаргонизмы (В.М. Жирмунский, Л.П. Крысин), профессиональные термины, профессиональная терминология (Б.Л. Богородский, О.Н. Трубачев), профессиональное просторечие, производственные жаргонизмь (М.А. Грачев) и др. С целью устранения терминологической неточности и выявления базовых свойств лексика профессиональной речи классифицируется в статье по следующим признакам: способы номинации, нормативность, функционально-стилевые характеристики, эмоционально-экспрессивная характеристика, словарная фиксация. Предложенная классификация позволяет выявить три группы лексики - терминология, собственно профессиональная лексика и профессиональный жаргон - каждая из которых обладает собственными характеристиками. Представляется, что выявленные критерии и характеристики структурных единиц профессионального языка могут рассматриваться как базовые.
\end{abstract}

Ключевые слова: Русский Язык, Профессиональная Лексика, Социальный Диалект, Терминология, Жаргон.

1. E-mail: daniil_vinogradov@icloud.com 


\section{Введение}

Несмотря на общепризнанность в отечественной лингвистике в течение длительного времени такого объекта описания и изучения, как профессиональный язык (профессиональная лексическая система), его внутренняя неоднородность и терминологическая идентификация является важной теоретической проблемой и в настоящее время.

Теоретические принципы, заложенные в 1930-е признанными классиками данного направления русистики Б.А. Лариным (Ларин 1977) и В.М. Жирмунским (Жирмунский 1936) получили дальнейшее осмысление в трудах А.В. Суперанской (Суперанская, Подольская, Васильева 1989), в работах Л.П. Крысина (Крысин 2004, 2013) и В.И. Беликова (Беликов, Крысин 2001). Особое значение в фокусе нашего исследования обретает изучение жаргонных и арготических систем, осуществленное В.Д. Бондалетовым (Бондалетов 1987) и М.А. Грачевым (Грачев 2011).

В нашей статье сделана попытка рассмотреть не только различные гипотезы отечественных лингвистов о природе профессионального языка (профессиональной лексической системы), но и предложить ясные критерии выявления структурных единиц профессионального языка, которые могут рассматриваться как базовые при проведении новых исследований в данной области.

\section{Основная часть}

Профессиональная лексика, являясь принадлежностью социальнопрофессиональных групп, относится к социально-детерминированным формам речи. Любая социально-детерминированная форма речи традиционно относится к системе социальных диалектов (см., например, (Степанов 1975. 198)), реализуя функцию последних как средства общения «лиц, входящих в определенную социальную или профессиональную группировку», призванных 
«объединять членов в одну корпорацию, имеющую свои интересы профессиональные, социально-сословные, возрастные, культурноисторические и т. п.» (Бондалетов 1987. 68). Под социальными диалектами понимается «язык определенных социальных групп. Таковы отличающиеся от общенародного языка только лексикой профессиональные языки охотников, рыболовов... и др.; групповые, или корпоративные, жаргоны или сленги учащихся, студентов, спортсменов и других, гл. обр. молодежных, коллективов; тайные языки, арго деклассированных элементов, ремесленников-отходников, торговцев. Таковы также варианты общенародного языка, характерные для определенных экономических, кастовых, религиозных групп населения» (ЛЭС 1990. 133).

В классификациях социальных диалектов профессиональные языки обычно занимают достаточно определенное место. В 1960-е годы В.Д. Бондалетовым была предложена классификация социальных диалектов в зависимости от их природы, назначения, языковых признаков и условий функционирования. С некоторыми уточнениями она была воспроизведена в его книге «Социальная лингвистика» (1987 г.). В.Д. Бондалетов называет 4 типа явлений, относимых им к социальным диалектам.

1. Первый тип явлений представляет собой собственно профессиональные «языки» (точнее - лексические системы), например, рыболовов, охотников, гончаров, деревообделочников, сапожников и др. Профессиональные «языки» - это дополнительные к основной форме существования языка (литературному языку, территориальному диалекту) лексические системы, свойственные представителям определенного занятия, промысла, профессии или отрасли производства. Существуют тысячи профессий, и у каждой свой «язык» (точнее, лексическая система). Количество «профессионализмов» зависит от степени развитости и специализации соответствующего производства. В качестве примера профессионализмов В.Д. Бондалетов приводит такие 
единицы, как: кок (повар) в речи моряков, на-гора - шахтеров, правило (хвост лисицы) - охотников, матка, трутень, рабочая пчела - пчеловодов.

Профессиональные «языки» - не языки в полном смысле этого слова, их собственно языковая часть ограничивается специализированной лексикой и частично словообразованием, не распространяясь на фонетику и грамматику.

2. Вторую группу составляют групповые, или корпоративные, жаргоны, например, учащихся, студентов, спортсменов, солдат и других, главным образом молодежных коллективов. Групповые жаргоны в отличие от профессиональных социолектов порождены не потребностью в назывании новых понятий, а стремлением дать общеизвестным понятиям свое обозначение, отличающееся новизной и экспрессией. Лексика жаргона - это параллельный ряд слов и выражений, синонимичных первичному, нежаргонному ряду. Поскольку жаргонизмами обозначают в основном уже известное (предмет, качество, состояние), то здесь мы имеем дело с синонимами не понятийными, а почти исключительно экспрессивнооценочными.

3. Третью группу явлений составляют условные языки (арго) ремесленников-отходников, торговцев и близких к ним социальных групп. Условные языки (арго) - лексические системы, предназначенные для выполнения преимущественно конспиративной функции. Потребность в использовании тайного, непонятного для непосвященных языка возникает у социальных групп, стремящихся сознательно изолировать себя от основной части общества. В России условные языки (арго) имели распространение среди тех, кто занимался отходными промыслами: ремесленников (портных, шорников, каменщиков и т. д.), сезонных рабочих и др.

4. К четвертой группе явлений В.Д. Бондалетов относит жаргон (арго) деклассированных (Бондалетов 1987. 69).

Ст. Стойков, на материале болгарского языка, предлагает следующую классификацию социальных диалектов: 1) профессиональные говоры и 
2) жаргоны; которые подразделяются на 1) тайные говоры, 2) групповые говоры, 3) классовые говоры (Стойков. 1957).

В классификации А.А. Леонтьева и др. в работе «Речь в криминалистике и судебной психологии» основные свойства профессиональных языков представлены еще более четко: 1) профессиональные языки (номинация только предметов и явлений профессиональной сферы), 2) жаргоны (номинация актуальных понятий), 3) условные языки (арго) (номинация как профессиональных, так и общеизвестных понятий) (Леонтьев, Шахнарович, Батов. 1977).

Таким образом, этот тип социальных диалектов определяется практически однозначно и имеет ряд принципиальных свойств: все исследователи подчеркивают, что профессиональные языки - это собственно профессиональные лексические системы, в которых номинируются только предметь $и$ явления профессиональной сферы, соответственно профессиональная лексика представляет собой наименования собственно профессиональной сферы деятельности.

Несмотря на общую лингвистическую четкость данного объекта, он в различные периоды имел различные терминологические интерпретации, на которых необходимо остановиться подробнее.

Профессиональная лексика, профессиональная лексическая система до сих пор существует в совокупности следующих терминологических дублетов: профессиональный говор, профессиональный язык, профессиональное арго, профессиональный жаргон.

Характерно, что понятие «язык» (в имеющем терминологический характер словосочетании «профессиональный язык», употребляемом в научном обиходе вплоть до настоящего времени, - правда, с оговорками) имеет историческое соответствие непосредственно с предметом нашего исследования.

В XIX веке в русской лингвистике и в общем употреблении для обозначения профессиональных лексических систем нередко использовались 
словосочетания, включающие определение «язык»: «язык петербургских мазуриков» (воровская речь), «язык офеней» и т. д., получавшие, благодаря частому использованию, устойчивый терминологический характер. Примечательно, что данные «языки» часто воспринимались как закрытые, «тайные» системы, которым приписывалась ярко выраженная конспиративная функция (В.И. Даль, И.И. Срезневский и мн. др.).

Так, в 1936 году В.М. Жирмунский писал: «В сущности термин “профессиональный говор”, а тем более “профессиональный язык”, принятый в буржуазной лингвистике, основан на неправильном словоупотреблении: в исследованиях, посвященных “языку плотников”, “языку моряков” и т. п., речь идет только о некоторой специальной сфере профессиональной лексики внутри того или иного классового диалекта» (Жирмунский 1936. 105).

Широкое понимание термина арго в первой половине XX века привело к появлению терминологического сочетания профессиональное арго (Б.А. Ларин, Д.С. Лихачев).

Исследование социальных диалектов, возобновившееся в 60-е годы XX века после почти 30-летнего перерыва, вывело вопрос терминологии на новый уровень. Л.И. Скворцов в 1966 г. писал: «Частные понятия, такие как жаргон, арго, специальный язык, сленг и т. п., не имеют ... необходимой терминологической строгости определения. Они нередко употребляются без разбора, подменяют друг друга или получают неоднозначные, порой взаимоисключающие толкования» (Скворцов 1966. 5).

В современном языкознании терминологическая вариативность еще более увеличивается.

Профессиональная лексика в терминологии конца XX - начала XXI вв. может интерпретироваться как профессиональныци подъязык (Суперанская 1989, Крысин 1989). Л.П. Крысин к спещиальным подъязыкам относит: территориальные диалекты, просторечие, профессиональные жаргоны, социальные жаргоны (Крысин 1989, 2004). 
Профессиональная лексика также подпадает и под определение соичиолекта: «Социолектом называют совокупность языковых особенностей, присущих какой-либо социальной группе - профессиональной, сословной, возрастной и т. п. - в пределах той или иной подсистемы национального языка. Социолекты не представляют собой целостных систем коммуникации. Это именно особенности речи - в виде слов, словосочетаний» (Беликов, Крысин 2001. 47).

С учетом проблем дальнейшего анализа собранного материала подчеркнем еще один важный тезис. Важнейшей особенностью любой социальнодетерминированной формы речи является то, что она существует в лексиконе социальной группы наряду с литературными формами речи, а также наряду с другими социально и территориально детерминированными речевыми формами. Социальные диалекты возникают в ответ на различные профессиональные и групповые потребности отдельных коллективов, они всегда сосуществуют в речевой практике говорящих с другими формами существования языка, которые всегда выступают как первичные, основные (литературный язык, территориальные диалекты, просторечие), социальные же диалекты - как дополнение к ним. Это обусловлено в первую очередь тем, что любой человек (как и совокупность людей - социальная группа) «сопринадлежит одновременно нескольким разным по охвату коллективам» (Ларин 1977. 178).

Таким образом, рассматривая одну профессиональную лексическую систему, мы неизменно имеем дело с фактами ее взаимодействия как с литературным языком, территориальными диалектами, так и с другими формами собственно социальных диалектов (жаргонами, арго).

Таким образом, профессиональная лексика является такой формой социальных диалектов, которая в классификациях социальных диалектов интерпретируется однозначно как профессиональный язык, и представляет в 
своей основе собственно профессиональную лексическую систему, в которой номинируются только предметы и действия профессиональной сферы.

Несмотря на то, что в различных классификациях социальных диалектов профессиональный язык (профессиональная лексическая система) вычленяется достаточно четко, то его внутренняя неоднородность и терминологическая идентификация давно является сложнейшей теоретической проблемой.

Так, лексика профессиональной речи на протяжении истории ее изучения называлась и называется в различных исследованиях по-разному: терминология, технические слова (Д.К. Зеленин), арготическая профессиональная лексика, профессиональное арго, профессиональные арготизмы (Б.А. Ларин, Д.С. Лихачев), профессиональные жсаргоны, профессиональные жаргонизмы (В.М. Жирмунский, Л.П. Крысин), профессиональные термины, профессиональная терминология (Б.Л. Богородский, О.Н. Трубачев), профессиональный подъязык (О.В. Борхвальдт), профессиональное просторечие, производственные жаргонизмы (М.А. Грачев), профессионализмы (Н.М. Шанский, О.С. Ахманова и др.), специальная лексика (В.М. Лейчик, С.Д. Шелов) и т.п. Из современных работ добавим также профессиональное арго, профессиональный сленг, профессиональный диалект, специиальный язык, профессионально-диалектное просторечие.

Внутреннюю противоречивость рассматриваемой формы социальных диалектов объяснил Л.П. Крысин: «...профессиональные жаргоны подобны стилям литературного языка: их использование зависит от условий общения (ситуации, цели, темы, адресата и т.п.). Однако, в отличие от стилей, каждый профессиональный жаргон имеет строго определенную и притом ограниченную среду, в которой он используется и за пределами которой он непонятен. Профессиональный жаргон, таким образом, как бы совмещает в 
себе коммуникативные признаки стиля и социальные признаки корпоративного (группового) жаргона» (Крысин 2004. 6).

Являясь средством профессионального общения, профессиональный язык (профессиональная лексическая система) содержит, как минимум, и специальные профессиональные термины, и разговорные слова, понятные только представителям данной профессии (профессионализмы). И профессионализмы, и термины входят в состав профессиональной (отраслевой, специальной) лексики, являющейся частью общей лексической системы языка.

В общей массе слов, употребление которых свойственно людям тех или иных профессий, имеющих сферой своего использования какую-либо отрасль техники или науки, Л.П. Крысин различает лексику спецุиальную и профессиональную, понимая под первой «официально принятые и регулярно употребляемые специальные термины», а под второй - «свойственные многим профессиям экспрессивно переосмысленные, переиначенные слова и выражения, взятые из общего оборота» (Крысин 2013. 144-145).

Признавая за термином ряд особенностей, отличающих его от общеупотребительного слова (нахождение термина в системе других терминов, относящихся к данной отрасли знания и образующих терминологическое поле, моносемичность и наличие дефиниции, а также стилистическую нейтральность), более или менее подробно Л.П. Крысин останавливается только на последней характеристике, оговаривая то, что профессионализм как единица профессиональной лексики часто стилистически окрашен и обладает определенной экспрессией.

Важнейшими характеристиками терминов являются «системность, наличие дефиниции (для большинства терминов), тенденция к моносемичности в пределах своего терминологического поля, а также отсутствие экспрессии и стилистическая нейтральность» (ЛЭС 1990: 508-509). Кроме того, 
неоспоримыми характеристиками терминов являются их социально обязательный характер, а также связь с научными концепциями, отмечаемая исследователями в качестве «основной черты, отличающей термины от слов всех других типов» (Суперанская 1989. 7-8). Тезис о том, что «термин (для лингвиста. - Д. В.) - это имя понятия, а дефиниция - развернутое толкование этого имени» (Суперанская 1989. 11), приводит к следующему утверждению: «Под термином понимается слово или лексикализованное словосочетание, требующее для установления своего значения в соответствующей системе понятий построения дефиниции» (Канделаки 1977. 7).

Однако представители той или иной профессии оперируют в своей речи не только терминами, но и профессионализмами, которые, как и термины, представляют собой слова и выражения, обозначающие понятия специальной сферы деятельности. Профессионализмы, как и термины, могут проникать в общенародный язык, преимущественно в устную речь, становясь известными той части населения, которая непосредственно со сферой деятельности, «породившей» то или иное слово, не сталкивается (например, задраить ‘плотно закрыть' (из речи моряков), вырубить 'выключить' (из речи электротехников).

В разговорный язык профессионализмы (элементы профессионального просторечия) проникают благодаря своей эмоциональной выразительности, отвечая постоянной потребности носителей языка в обновлении лексического, особенно экспрессивного, инвентаря, а также потребности в языковой игре. Благодаря своей выразительности, которую можно считать одним из конститутивных свойств профессионализмов, а также порой встречающейся близости значений, профессионализмы могут выступать как просторечные, эмоционально окрашенные эквиваленты терминов (программер, компьютерщик и программист, сисадмин и системныйадминистратор, вертушка и вертолет). 
В отечественной лингвистике широко распространена и терминология, представленная в ряде работ Л.П. Крысина. Как отмечает исследователь, к разновидностям общенародного языка, кроме территориальных и социальных диалектов, относятся и жаргоны, в том числе - профессиональные, также присущие более или менее ограниченным группам людей, имеющие, таким образом, ограниченную сферу употребления.

Профессиональный жаргон используется только среди людей определенной профессии, «да и то, как правило, при их общении на деловые, производственные темы. В иных же ситуациях, при общении с людьми, не владеющими данной профессией, а особенно при использовании письменной формы языка, человек обычно прибегает к помощи литературных языковых средств...» (Крысин 2007. 8-9).

Профессиональный жаргон присущ людям, которых объединяет общая профессия, и используется главным образом при общении на производственные темы (брюхо - 'нижняя часть фюзеляжа' в жаргоне летчиков, мотыль - 'моторист' у моряков). Иная терминологическая трактовка данного понятия не мешает сущностному и наиболее распространенному его именованию и как профессионализм, профессиональная лексика.

Таким образом, на терминологическую вариативность наименования самого объекта (профессиональный язык) накладывается проблема его внутренней структурной неоднородности, что приводит к употреблению таких наименований, как термины и профессионализмы.

Однако и содержание данных понятий в отношении к структурным единицам профессионального языка не вполне однозначно.

Остановимся на нескольких обобщающих работах, посвященных этой проблеме, которые претендуют на ее решение, хотя бы и относительное. 
С.Д. Шелов дал системный обзор всех существующих терминологических концепций и обобщил основные интерпретации профессиональной лексики, которые позднее расширил в работе (Шелов, Лейчик 2012). Ученый, рассматривая обобщенно лексику профессиональной сферы употребления как специальную, четко выделяет в ее составе: профессиональную лексику и терминологическую, и выявляет следующие терминологические концепции их соотношения в отечественной лингвистике:

1) отождествление профессиональной лексики и терминологии (В.М. Жирмунский, А.А. Реформатский, Н.М. Шанский, О.С. Ахманова);

2) различение профессиональной лексики и терминологии а) по хронологическому принципу (М.Д. Степанова, И.И. Чернышева, B.Н. Портянникова, F.Kluge): профессиональная лексика архаична, терминология - специальная лексика современной науки и техники; б) по номинативному принципу (А.В. Калинин, Б.И. Косовский): «большая точность терминологической лексики - меньшая точность профессиональной лексики» (Шелов 1984. 79);

3) частичное совпадение и частичное разделение профессиональной лексики и терминологии, что неизбежно ведет к дифференциации профессиональной лексики, одной из частей которой оказываются собственно профессионализмы, которые не являются терминами (А.В.Калинин, Н.Н. Медведева, В.Н. Прохорова, С.И. Сердобинцева, Н.И. Фомина, С.Д. Шелов,).

С конца XX в. в структуру профессиональных лексических систем ряд исследователей включают не 2, а 3 и иногда 4 группы языковых явлений (Е.И. Голованова, М.А. Грачев, Е.И. Квашнина, В.Н. Прохорова).

Системную классификацию профессиональной лексики провела Е.И. Голованова, которая на основании учета функционально-стилистических и эмоционально-экспрессивных характеристик выделила 
- терминология и номенклатура (книжные слова),

- устный профессиональный язык, профессионализмы (разговорные слова),

- профессиональные жаргонизмы (просторечие) (Голованова 2008) 1.

Той же классификации придерживается М.А. Грачев, включая и иные критерии дифференциации профессиональной лексики (Грачев 2011).

Обобщим сделанные исследователями выводы в следующей таблице:

\begin{tabular}{|c|c|c|c|}
\hline $\begin{array}{c}\text { Предлагаемые } \\
\text { критерии }\end{array}$ & $\begin{array}{c}\text { Термины/ } \\
\text { номенклатура }\end{array}$ & $\begin{array}{c}\text { Профессиональная } \\
\text { лексика, } \\
\text { профессионализмы }\end{array}$ & $\begin{array}{c}\text { Профессиональные, } \\
\text { производственные } \\
\text { жаргонизмы }\end{array}$ \\
\hline $\begin{array}{c}\text { Способы } \\
\text { номинации }\end{array}$ & первичная номинация & $\begin{array}{c}\text { первичная/вторичная } \\
\text { номинации } \\
\text { профессиональных } \\
\text { понятий }\end{array}$ & \begin{tabular}{|c} 
вторичная (по \\
отношению к терминам и \\
профессионализмам) \\
номинация
\end{tabular} \\
\hline $\begin{array}{c}\text { Нормативные } \\
\text { характеристики }\end{array}$ & нормированы & ненормированы & ненормированы \\
\hline $\begin{array}{l}\text { Функционально- } \\
\text { стилевые } \\
\text { характеристики }\end{array}$ & $\begin{array}{c}\text { книжные слова } \\
\text { (письменная и устная } \\
\text { форма) }\end{array}$ & $\begin{array}{c}\text { разговорные слова } \\
\text { (устная форма) }\end{array}$ & $\begin{array}{c}\text { просторечие } \\
\text { (устная форма) }\end{array}$ \\
\hline $\begin{array}{c}\text { Эмоционально- } \\
\text { экспрессивная } \\
\text { характеристика }\end{array}$ & $\begin{array}{c}\text { высокая, нейтральная } \\
\text { лексика } \\
\text { (отсутствует } \\
\text { коннотация) }\end{array}$ & $\begin{array}{c}\text { нейтральная лексика } \\
\text { (отсутствует или } \\
\text { возможна коннотация) }\end{array}$ & $\begin{array}{c}\text { сниженная лексика } \\
\text { (обязательна коннотация) }\end{array}$ \\
\hline $\begin{array}{c}\text { Фиксация в } \\
\text { словарях }\end{array}$ & $\begin{array}{c}\text { нормативные словари, } \\
\text { терминологические } \\
\text { словари }\end{array}$ & \begin{tabular}{|c|} 
не фиксируются в \\
толковых и нормативных \\
словарях, \\
словари \\
профессионализмов, \\
жаргонизмов
\end{tabular} & $\begin{array}{c}\text { не фиксируются в } \\
\text { толковых и нормативных } \\
\text { словарях, } \\
\text { жаргонные, диалектные } \\
\text { словари }\end{array}$ \\
\hline
\end{tabular}

Рассматривая дифференциальные признаки трехступенчатой классификации, можно заметить, что профессиональное просторечие обладает меньшим набором дифференциальных признаков, чем термины и профессионализмы.

1. Трудно согласиться с проводимой в (Шелов, Лейчик 2012) классификацией профессиональной лексики, в которой авторы, в частности, различают профессиональные жаргонизмы и профессиональное просторечие, однако четких дифференциальных признаков разграничения последних не обнаруживается. 
Представляется, что теоретически и логически выявленные критерии и характеристики структурных единиц профессионального языка могут в целом рассматриваться как базовые.

Считаем необходимым отдельно остановиться на таком важном вопросе, как рассмотрение профессиональных лексических систем в историческом аспекте. Традиционно лексика различных промыслов или профессиональная лексика в различные исторические периоды рассматривается в рамках русской диалектологии и исторической лексикологии. Значительная часть работ по профессиональным лексическим системам выполняется в аспекте традиционной исторической лексикологии: история слов, определение их генезиса, функционирования; классификация материала осуществляется по тематическим, лексико-семантическим группам или тематическим микрополям, - тем самым дается общая характеристика состава лексической системы данной профессии, ее исторической динамики, процессов номинации в ней и т.п.

Однако со второй половины XX в. стали появляться работы, посвященные специфике формирования профессиональных лексических систем в исторической перспективе (В.Н. Прохорова, Л.П. Рупосова, О.Н. Трубачев и др.), в связи с чем лексика той или иной профессиональной группы на историческом фоне начала рассматриваться в аспекте исторического терминоведения, результатом чего стали новые парадигмы теоретического осмысления и классификации ее единиц.

Так, большинство ученых в отношении профессиональной лексики, возникающей в древнерусский и старорусский период, сходятся в аспекте ее номинативно-денотативного своеобразия. В отличие от современных терминосистем для древних профессиональных очевидна детерминированность общенародным языком (В.Н.Прохорова, Ф. П. Сороколетов, Ю. И. Чайкина, Н. А. Щеглова и др). Поэтому неслучайно, 
что в ранних профессиональных системах так много составных наименований и мало заимствований (О. В. Борисова, Ф. П. Сороколетов). Именно поэтому в ряде различных профессиональных терминосистем используются одни и те же наименования, которые исследователи назвали «сквозными профессионализмами» (Чайкина, Зорина 1982).

Древним «терминам» (или «профессионализмам») свойственна «произвольность» (Ф.П. Сороколетов), нестрогая понятийная наполненность (Г.П. Снетова), свободное содержание (Н.А. Щеглова). Такую донаучную, «наивную» «терминологию», например, Н.А. Щеглова предложила считать «предметной» (Щеглова 1964. 9).

Основными свойствами «терминов» в ранних профессиональных системах можно считать:

- многозначность;

- неточность, недифинированность, неопределенность значения;

- наличие дублетности и широкой синонимии;

- несистемная гиперонимия (например, наличие значительного числа гипонимов при отсутствии гиперонима) и т.п. (Б.Л. Богородский, Ф.П. Сороколетов).

О.Н. Трубачев по целевым установкам профессиональной номинации в исторической перспективе выделил cmaтуальные и генуинные терминологическое наименования. Статуальные являются вторичными номинациями: имеющиеся в языке слова лишь используются в данной профессиональной системе. Генуинные наименования - номинации, изначально возникающие как условные термины в данной профессиональной сфере (Трубачев 1966. 64-65).

Важность «диахронической» природы профессионализмов в аспекте их возможного разграничения с терминологией подчеркивается Шеловым и Лейчиком: «Социальные характеристики слов, обозначающие 
профессиональные понятия, в период, предшествующий образованию национальных государств и формированию национальных языков, и слов той же группы в период развитых национальных языков не могут не быть глубоко различны» (Шелов, Лейчик 2012. 35).

В современном историческом терминоведении динамический характер формирования терминосистем пропорционально передается в следующих наименованиях:

Прототермины - это специальные наименования, которые называют «представления о каком-либо объекте, явлении, процессе, а также их свойстве и качестве», возникают в донаучный период, не имеют связи с научным понятием, недифференцированы, имеют случайную мотивированность и тесно связаны с общенародным языком, стилистически нейтральны, имеют относительно устойчивое лексическое значение (Борхвальдт 2000. 25).

В донациональный период незначительно отличаются друг от друга терминоиды и предтермины.

Терминоиды - это специальные лексические единицы, которые используются для называния формирующихся, неустоявшихся понятий; они появляются в период зарождения научных знаний и не имеют четких дефиниций.

Предтермины - это специальные наименования для обозначения научных понятий молодых наук (Борхвальдт 2000. 26-27).

Принципиально следует отличать от данных этапов формирование собственно терминов - наименований научных или номенклатурных понятий.

Профессионализмы - лексические единицы, называющие предметы, процессы и пр., использующиеся в различных промыслах и ремеслах только в устной форме и в неофициальной обстановке; как правило, локально ограниченные, могут бать как стилистически нейтральными, так и эмоционально-окрашенными. 
Современные термины могут формироваться на базе всех указанных типов терминологических наименований. Однако, по мнению Л.П. Рупосовой, в историческом плане профессиональная лексика вычленяется «более определенно» (Рупосова 1994). Приведем основные обобщения исследователя:

- «профессионализм выступает как номен и не имеет присущих термину родо-видовых отношений, хотя может обладать развитыми видо-подвидовыми отношениями»;

- «денотативная сущность профессионализма является его основным признаком, а это ведет к открытости классов профессионализмов, где отношения “предмет” - “имя”, “явление” - “имя” удовлетворяют потребности специалистов без построения классификационных схем»;

- «соотношение с понятием у профессионализма ослаблено по сравнению с термином; в отличие от термина профессионализм не нормирован; в число профессионализмов достаточно свободно входят диалектизмы»;

- «профессионализм имеет более глубокие связи с общим языком»;

- «профессионализм может обладать экспрессивностью; профессионализмы в своем большинстве быстро входят в массовое употребление, а термины остаются известными только специалистам»;

- «профессионализм может иметь “игровой характер”»;

- «для профессиональной лексики типична мотивированность языковой формы»;

- «профессионализмы могут предшествовать становлению терминологии соответствующей области» (Рупосова 1994. 8-9).

\section{Заключение}

Несмотря на изучение профессиональной лексики отечественными лингвистамина протяжении длительного времени, внутренняя неоднородность и даже терминологическая идентификация объекта изучения до сих пор остаются сложнейшими теоретическими проблемами. 
Использование предложенной нами классификациипрофессиональной лексики позволяетвыявить три группы лексики - терминология, собственно профессиональная лексика и профессиональный жаргон - каждая из которых обладает собственными характеристиками. Представляется, что предложенная в статье классификация, основанная на четких критериях и характеристиках структурных единиц профессионального языка, позволит в дальнейшем упростить исследователям анализ профессиональных лексических систем.

\section{Литература}

1- Беликов В. И., Крысин Л. П.(2001). Социолингвистика. -М.: РГГУ.

2- Бондалетов В. Д. (1987). Типология и генезис русских арго: учеб. пособие к спецкурсу / Рязан. гос. пед. ин-т им. С. А. Есенина. Рязань: Рязан. ГПИ.

3- Борхвальдт О. В. (2000). Лексика русской золотопромышленности $в$ историческом освещении. Красноярск: РИО КГПУ.

4- Голованова Е. И. (2008). Когнитивное терминоведение. Челябинск: Изд-во «Энциклопедия».

5- Грачев М. А. (2011). Составные части лексической системы профессиональных языков: $\kappa$ проблеме разграничения терминов, профессионализмов и производственных жсаргонизмов// Соииальные варианты языка-VII: Материаль международной научной конференции 14-15 апреля 2011. Нижний Новгород / отв. ред. М. А. Грачев. Нижний Новгород: Изд-во НГУ. С. 62-65.

6- Жирмунский В. М. (1936). Национальный язык и сочиальные диалекты / Ленинград. научно-исслед. ин-т языковедения ЛИФЛИ. -Л.: Изд-во «Худ. лит.»

7- Лингвистический энияилопедический словарь (1990) / Гл. ред. В. Н. Ярцева. М.: Изд-во «Сов. энциклопедия».

8- Канделаки Т. Л. (1977). Семантика и мотивированность терминов / АН СССР, Комитет научно-технич. терминологии. -М.: Изд-во «Наука».

9- Крысин Л.П. (1989). О речевом поведении человека в мальх соииальных обществах (постановка вопроса) // Язык и личность: сб. ст. / АН СССР, Ин-т рус. яз; Отв. ред. Д. Н. Шмелев. -М.: Изд-во «Наука». С. 78-86.

10- Крысин Л.П. (2004, 2013). Русское слово, свое и чужое: Исследования по современному русскому языку и соииолингвистике. Современный русский язык. М.: Языки славянской культуры. -М.: Издат. центр «Академия». 
11- Ларин Б. А. (1977). О лингвистическом изучении города // Ларин Б. А. История русского языка и общее языкознание. -М.: Изд-во «Просвещение». С. $175-189$.

12- Рупосова Л. П. (1994). Профессиональная лексика и терминология 6 историческом аспекте // Проблемы исторической терминологии: межвуз. темат. сб. науч. тр. / Мин-во РФ, Красноярск. пед. гос. ун-т; [Редкол.: О. В. Борхвальдт (отв. ред.)]. Красноярск: Изд-во КПГУ. С. 3-9.

13- Скворцов Л. И. (1966). Жаргонная лексика в языке художественной литературы // Bопросы культуры речи. Bыл. 7: сб. статей. -М.: Изд-во «Наука». С. 142-163.

14- Степанов Ю. С. (1975). Основы общегго языкознания. 2-е изд., перераб. -М.: Изд-во «Просвещение».

15- Суперанская А.В., Подольская Н.В., Васильева Н.В. (1989). Общая терминология: Вопросы теории. -М.: Изд-во «Наука».

16- Трубачев О.Н. (1966). Ремесленная терминология в славянских языках (этимология и опыт групповой реконструкиии). М.: Изд-во «Наука».

17- Шелов С.Д. (1984). Терминология, профессиональная лексика и профессионализмы (к проблеме классификации специиальной лексики)// Вопросы языкознания. №5. С. 76-87.

18- Шелов С.Д., Лейчик В.М. (2012). Терминология и профессиональная лексика: состав и функиии: учеб. пособие. -СПб.: Филологич. фак-т СпбГУ.

19- Щеглова Н. А. (1964). Терминологическая лексика оружейножелезоделательного производства XVII-XVIII вв. (По материалам памятников письменности Тульского края): автореф. дис. ... канд. филол. наук: 10.02.01. M.

\section{Bibliography}

1- Belikov V. I., Krysin L. P.(2001). Sociolingvistika.-M.: RGGU.

2- Bondaletov V. D. (1987). Tipologija i genezis russkih argo: ucheb. posobie $k$ speckursu / Rjazan. gos. ped. in-t im. S. A. Esenina. Rjazan': Rjazan. GPI.

3- Borhval'dt O. V. (2000). Leksika russkoj zolotopromyshlennosti v istoricheskom osveshhenii. Krasnojarsk: RIO KGPU.

4- Golovanova E. I. (2008). Kognitivnoe terminovedenie. Cheljabinsk: Izd-vo «Jenciklopedija». 
5- Grachev M. A. (2011). Sostavnye chasti leksicheskoj sistemy professional'nyh jazykov: $k$ probleme razgranichenija terminov, professionalizmov $i$ proizvodstvennyh zhargonizmov// Social'nye varianty jazyka-VII: Materialy mezhdunarodnoj nauchnoj konferencii 14-15 aprelja 2011. Nizhnij Novgorod / otv. red. M. A. Grachev. Nizhnij Novgorod: Izd-vo NGU. S. 62-65.

6- Zhirmunskij V. M. (1936). Nacional'nyj jazyk i social'nye dialekty / Leningrad. nauchno-issled. in-t jazykovedenija LIFLI. -L.: Izd-vo «Hud. lit.»

7- Lingvisticheskij jenciklopedicheskij slovar' (1990) / Gl. red. V. N. Jarceva. M.: Izdvo «Sov. jenciklopedija».

8- Kandelaki T. L. (1977). Semantika i motivirovannost' terminov / AN SSSR, Komitet nauchno-tehnich. terminologii. -M.: Izd-vo «Nauka».

9- Krysin L.P. (1989). O rechevom povedenii cheloveka $v$ malyh social'nyh obshhestvah (postanovka voprosa) // Jazyk i lichnost': sb. st. / AN SSSR, In-t rus. jaz; Otv. red. D. N. Shmelev. -M.: Izd-vo «Nauka». S. 78-86.

10- Krysin L.P. (2004, 2013). Russkoe slovo, svoe $i$ chuzhoe: Issledovanija po sovremennomu russkomu jazyku i sociolingvistike. Sovremennyj russkij jazyk. M.: Jazyki slavjanskoj kul'tury. M.: Izdat. centr «Akademija».

11- Larin B. A. (1977). O lingvisticheskom izuchenii goroda // Larin B. A. Istorija russkogo jazyka i obshhee jazykoznanie. -M.: Izd-vo «Prosveshhenie». S. 175-189.

12- Ruposova L. P. (1994). Professional'naja leksika i terminologija v istoricheskom aspekte // Problemy istoricheskoj terminologii: mezhvuz. temat. sb. nauch. tr. / Minvo RF, Krasnojarsk. ped. gos. un-t; [Redkol.: O. V. Borhval'dt (otv. red.)]. Krasnojarsk: Izd-vo KPGU. S. 3-9.

13- Skvorcov L. I. (1966). Zhargonnaja leksika v jazyke hudozhestvennoj literatury // Voprosy kul'tury rechi. Vyp. 7: sb. statej. -M.: Izd-vo «Nauka». S. 142-163.

14- 14.Stepanov Ju. S. (1975). Osnovy obshhego jazykoznanija. 2-e izd., pererab. -M.: Izd-vo «Prosveshhenie».

15- Superanskaja A.V., Podol'skaja N.V., Vasil'eva N.V. (1989). Obshhaja terminologija: Voprosy teorii. -M.: Izd-vo «Nauka».

16- Trubachev O. N. (1966). Remeslennaja terminologija v slavjanskih jazykah (jetimologija i opyt gruppovoj rekonstrukcii). -M.: Izd-vo «Nauka».

17- Shelov S.D. (1984). Terminologija, professional'naja leksika i professionalizmy ( $k$ probleme klassifikacii special'noj leksiki)// Voprosy jazykoznanija. №5. S. 76-87.

18- Shelov S.D., Lejchik V.M. (2012). Terminologija i professional'naja leksika: sostav i funkcii: ucheb. posobie. $-\mathrm{SPb}$.: Filologich. fak-t SpbGU. 
19- Shheglova N. A. (1964).sh Terminologicheskaja leksika oruzhejnozhelezodelatel'nogo proizvodstva XVII-XVIII vv. (Po materialam pamjatnikov pis'mennosti Tul'skogo kraja): avtoref. dis. ... kand. filol. nauk: 10.02.01. M.

HOW TO CITE THIS ARTICLE

Виноградов Д. В. (2020). The Status of Professional Vocabulary

in the Language System. Issledovatel'skiy Zhurnal Russkogo

Yazyka i Literatury, 8(2), 11-33.

DOI: 10.29252 /iarll.16.11

URL: http://journaliarll.ir/index.php/iarll/article/view/125

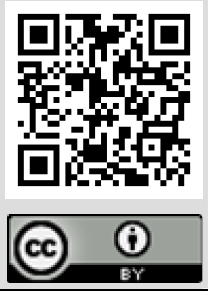




\title{
جايگاه وازگان حرفهاى و تخصصى در نظام زبان
}

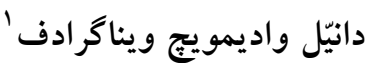

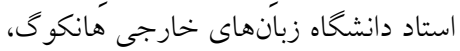

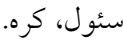 \\ (تاريخ دريافت: رانويه •r.r؛ تاريخ بذيرش: مه •r.r)
}

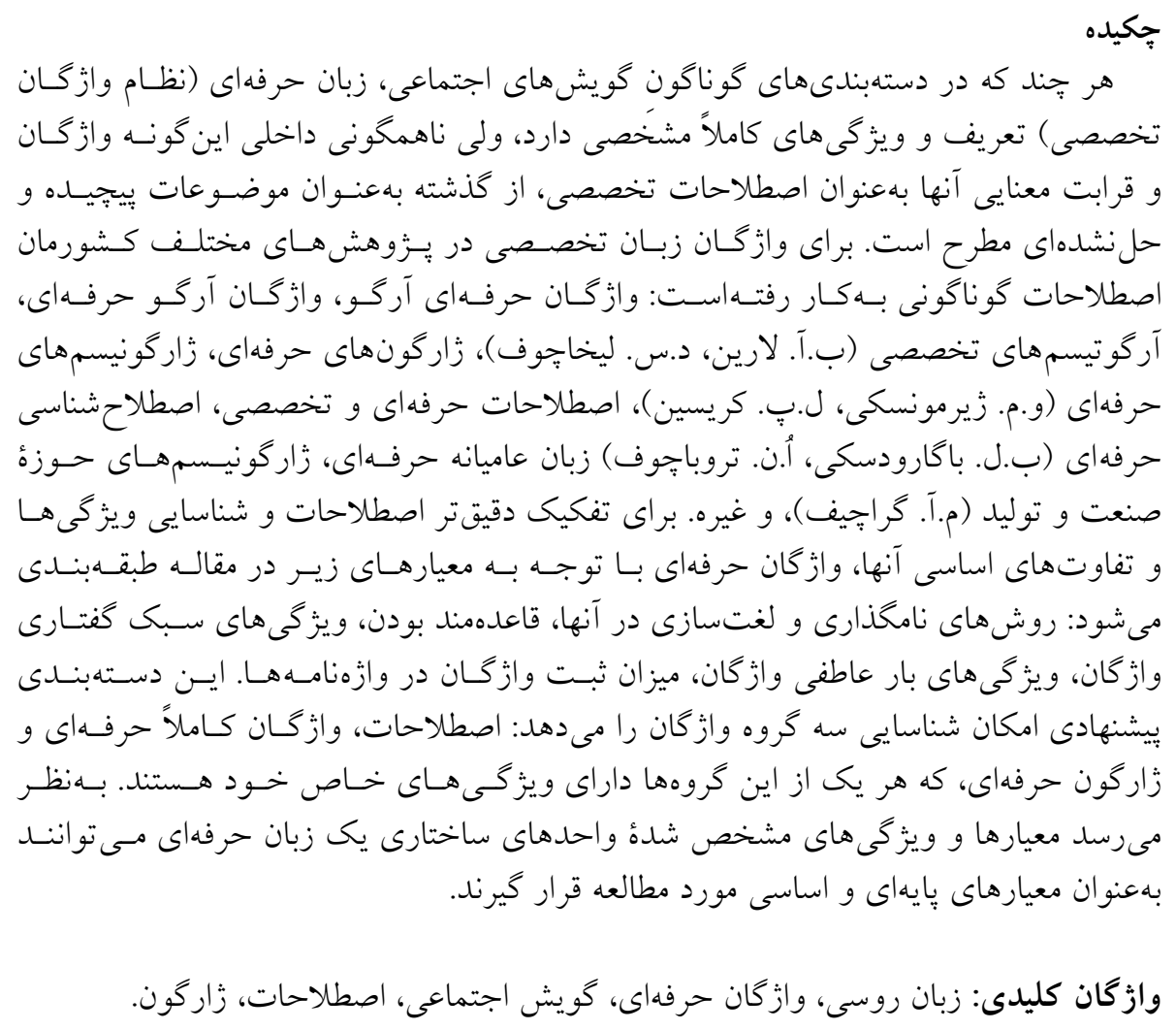

1. E-mail: daniil_vinogradov@icloud.com 